\title{
Fluvial trace fossils in the Middle Siwalik (Sarmatian-Pontian) of Darjeeling Himalayas, India
}

\author{
Abhijit Chakraborty ${ }^{1, *}$, Stephen T Hasiotis ${ }^{2}$, Bhaskar Ghosh ${ }^{1}$ \\ and Harendra Nath Bhattacharya ${ }^{3}$ \\ ${ }^{1}$ Department of Geology, Jogamaya Devi College, 92 S.P. Mukherjee Road, Kolkata 700 026, India. \\ ${ }^{2}$ Department of Geology, The University of Kansas, 1475 Jayhawk Blvd., rm. 120, Lindley Hall, \\ Lawrence, KS 66045-7594, USA. \\ ${ }^{3}$ Department of Geological Sciences, Presidency University, 86/1 College Street, Kolkata 700 073, India. \\ ${ }^{*}$ Corresponding author.e-mail: chakrabhiji@gmail.com
}

Trace fossils that record animal and plant activity are described for the first time from the Middle Siwalik, Neogene deposits of Darjeeling Himalaya. Sedimentary facies association attests to a channelinterchannel floodplain fluviatile setting. The intimate association of the burrows with phytoliths, rhizoliths, leaf compressions and coal lenses suggest that the tracemakers dominated a floodplain habitat. Point bar deposits host a low diversity Planolites-Naktodemasis-Macanopsis-Cylindricum equilibrium ichnocoenosis in the heterolithic fine sandstone-siltstone-shale facies that alternates with dense, monospecific colonization of Planolites as opportunistic pioneers relocating under stressed condition. Interlayered floodplain deposits in the fluvial successions preserve enigmatic large diameter, vertical tubes within thin to thick-bedded, dark silty shale facies. These tubes bear mixed characters assignable to both crayfish burrows and large-diameter rhizoliths. Further work on these tubes is necessary to make more accurate interpretations of those structures. Shallow to moderate burrow depths; intermittent, short-lived colonization events and preservation of rhizoliths and rhizohalos under fluctuating moisture content indicate short-term fluctuations of a relatively high water table (close to the paleosurface) in an imperfectly drained proximal floodplain setting. Ichnotaxa distribution and their inferred ethology provide significant faunal data that may put constraints on the reconstruction of Middle Siwalik depositional environment.

\section{Introduction}

The Siwalik basin contains a thick pile of alluvial deposits formed in a long, narrow, east-west trending foreland basin lying to the immediate south of Himalayan orogenic belt (Valdiya 1998; Vaidyanadhan and Ramakrishnan 2008). The study area (figure 1a) is in the foothills of eastern Darjeeling Himalayan segment where it exposes the Middle Siwalik Successions (Mallet 1875; Gansser 1964; Raju 1969; Chaudhri 1972; Banerjee and Banerjee 1982). Essentially continental, fluvial
Siwalik deposits (Kumar et al. 2004) are overridden in the north by Precambrian metamorphites (Dahling Group) across a thrust. A thin slice of coal-bearing Gondwana deposits is exposed as a tectonic window in between Precambrian rocks and the Siwaliks, which is traceable from Kalijhora in the west and Bagrakot in the east.

One road-cut section at sevoke road (Section-I; N26 54'2.49' (E088 28'15.07") and two river sections along Leesh river (Section-II; N26 55'16.3" / E088 32'34.8') and Gheesh river (Section-III; N26 $\left.54^{\prime} 19.6^{\prime \prime} / \mathrm{E} 08836^{\prime} 46.5^{\prime \prime}\right)$ in the study area have

Keywords. Trace fossils; Cenozoic; fluvial; molasse deposits; Middle Siwalik; Geology; biogeosciences. 


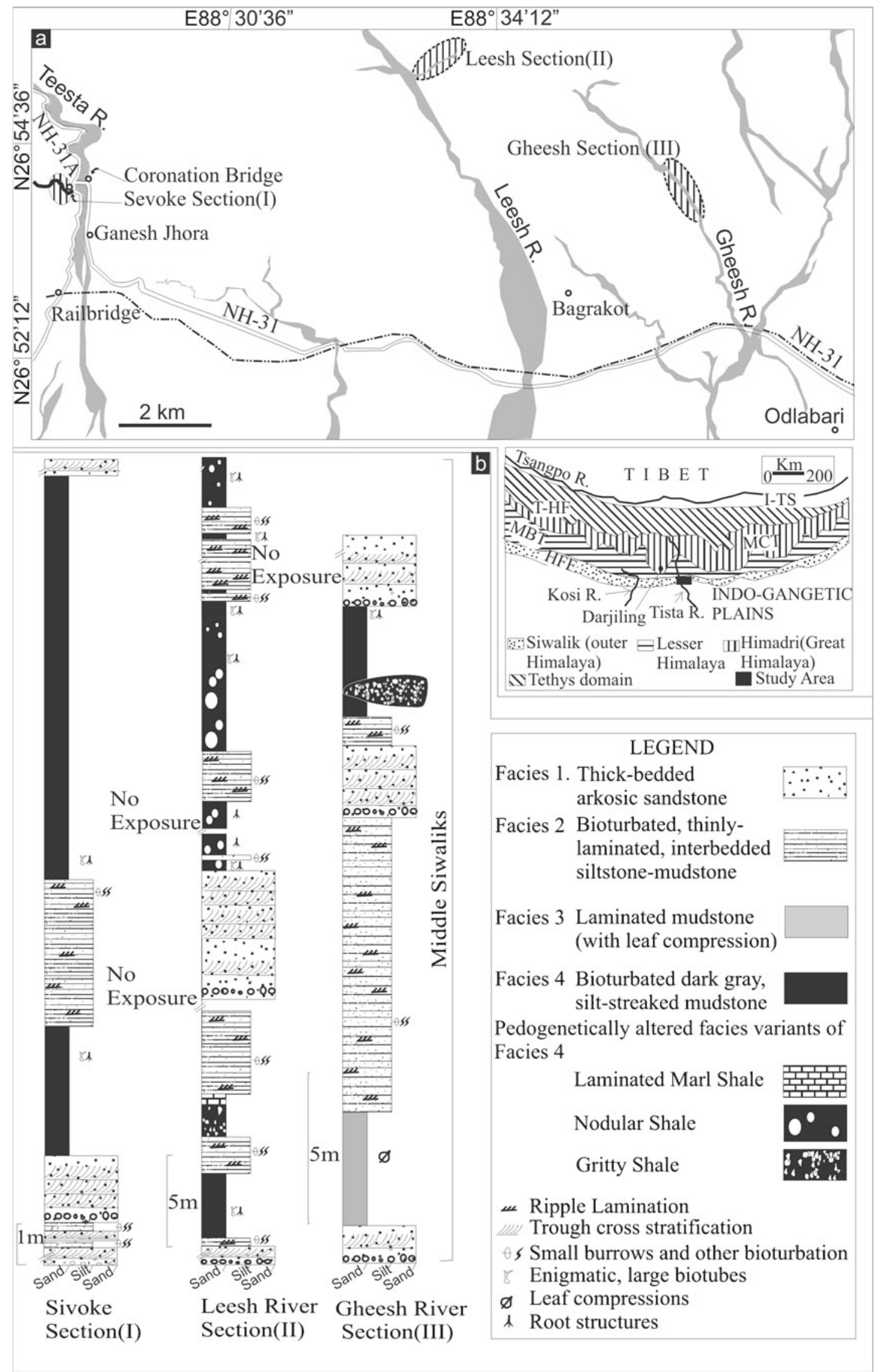

Figure 1. (a) Location map of the study area (inset regional map after Valdiya 1998) and (b) lithological successions of the Middle Siwaliks at Sevoke road cutting, Leesh River and Gheesh River sections. 
been studied in detail (figure 1b) primarily for their rich ichnological content.

A dearth of robust mammalian fossils and poorly preserved macroflora in Neogene Siwalik deposits, particularly in middle Miocene strata of Darjeeling Himalayas have forced researchers to interpret paleoenvironments based largely on sedimentological studies. Depositional environments have been interpreted as continental-fluviatile, alluvial fan-braided channel and meandering channelfloodplain-lacustrine (Mallet 1875; Gansser 1964; Acharyya et al. 1976; Banerjee and Banerjee 1982; Jain and Sinha 2003; Sanyal et al. 2005; Kundu et al. 2012). Few ichnological assessments available on Siwalik deposits are from upper Siwalik strata of Punjab Himalayas (Tandon and Naug 1984) and from areas to the west (Agarwal and Singh 1983). Significant ichna in the deposits of the study area have been overlooked until recently.

The present work describes the trace fossils from Middle Siwalik rocks of Darjeeling Himalayan area emphasizing on their morphological variations and ethological significance that may help to constrain the reconstruction of Siwalik depositional milieu based on new faunal data.

Four sedimentary facies types have been identified in the study area (figure 1b). These are respectively, thick-bedded arkosic sandstones, with frequent pebbly inter-layers (Facies-1); bioturbated, thinly interbedded, fining up sandstonesiltstone-shale (Facies-2); laminated mudstone with abundant leaf compressions (Facies-3) and bioturbated dark gray, silt-streaked mudstone (Facies-4). The sedimentary succession in the study area is interpreted as braided river channels with inter-channel floodplain deposits in which Facies1 represents channel deposits, Facies-2 represents point bar deposits with fining-up, ripple laminated to ripple-drift, cross-laminated intervals. Facies-3 and Facies-4 represent levee and proximal floodplain deposits, respectively. Presence of laminated marl shale and gritty and nodular marl shale are tentatively designated as facies variants of floodplain mudstone (Facies-4) that experienced varying degrees of pedogenic modification (e.g., Dubiel et al. 1992; Dubiel and Hasiotis 2011). The main occurrence of large-diameter, vertical tubes are in floodplain mudstones, whereas smaller burrows occur predominantly in levee and point bar deposits.

Neogene deposits of Siwalik Foreland Basin of Darjeeling Himalayas, exposed in road cuts and river sections along an east-west traverse between Sevoke (Darjeeling District) in the west and Malbazar area (Jalpaiguri District) in the east (figure $1 \mathrm{a}-\mathrm{b}$ ) were objectively studied in detail for their ichnological content. Facies-specific ichnotaxa were searched within thin, laminated sandstone-siltstone-shale facies and also within dark gray, silt-streaked mudstone that were rich in ichnological content. Attributes of these ichnotaxa, their lithofacies association and common association with leaf fossils, phytoliths and rhizoliths were examined in order to glean possible paleoecological and paleohydrological information that may constraint the interpretation of the paleoenvironment and post-depositional histories of these sediments.

\section{Materials and methods}

Trace fossils were described as eight distinct morphotypes based on architectural and surficial morphologies and burrow-fill sediment character (Häntzschel 1975; Hasiotis 2004). Trace fossil assemblages in the present work objectively embrace all trace fossils/morphotypes occurring within a single rock unit (single bed, bed couplet, recurrent interbeds) irrespective of whether or not the traces were produced simultaneously or as temporally separated bioturbation events (following definition of Bromley 1990). Seilacher's (1964, p. 306) original English definition of the term 'ichnocoenoses' was simply as 'trace associations'. However, from their lithofacies associations (within Facies-2 and 4), trace fossil assemblages have been grouped into ichnocoenoses (e.g., Hasiotis 1990; Hasiotis and Mitchell 1993; Smith et al. 2008a, b). Monospecific Planolites isp. in Facies-2 and enigmatic tubes in Facies-4 were given status of separate trace fossil assemblages following Keighley and Pickerill (2003).

Predicted moisture requirement of the probable trace makers (Hasiotis 2004, 2007, 2008) of these ichnocoenoses were used, in addition to other consequential, supportive pedogenetic evidences (e.g., Glinski and Lipiec 1990), for deciphering the paleohydrologic conditions of the host sediments after deposition.

\section{Result: description of morphotypes}

\subsection{Type 1 - Problematica (large-diameter, vertical tubes) (figures 2-4)}

Description: These are near vertical, commonly parallel-sided, silt or mud-filled tunnels; cross-sectional diameter range between 1.05 and $7.2 \mathrm{~cm}$ with common terminal enlargements (up to $20.5 \mathrm{~cm}$ ). Multiple tunnel enlargements are also present (figure 2a). Fine silt and clay lining with variable thickness along the length of tube is observable on bedding plane and in section (figure 2b), whereas some tunnels are coarse, with linings of sand (figures 2c, 3). Sediment fills of contrasted composition (clay and sand) co-exist 


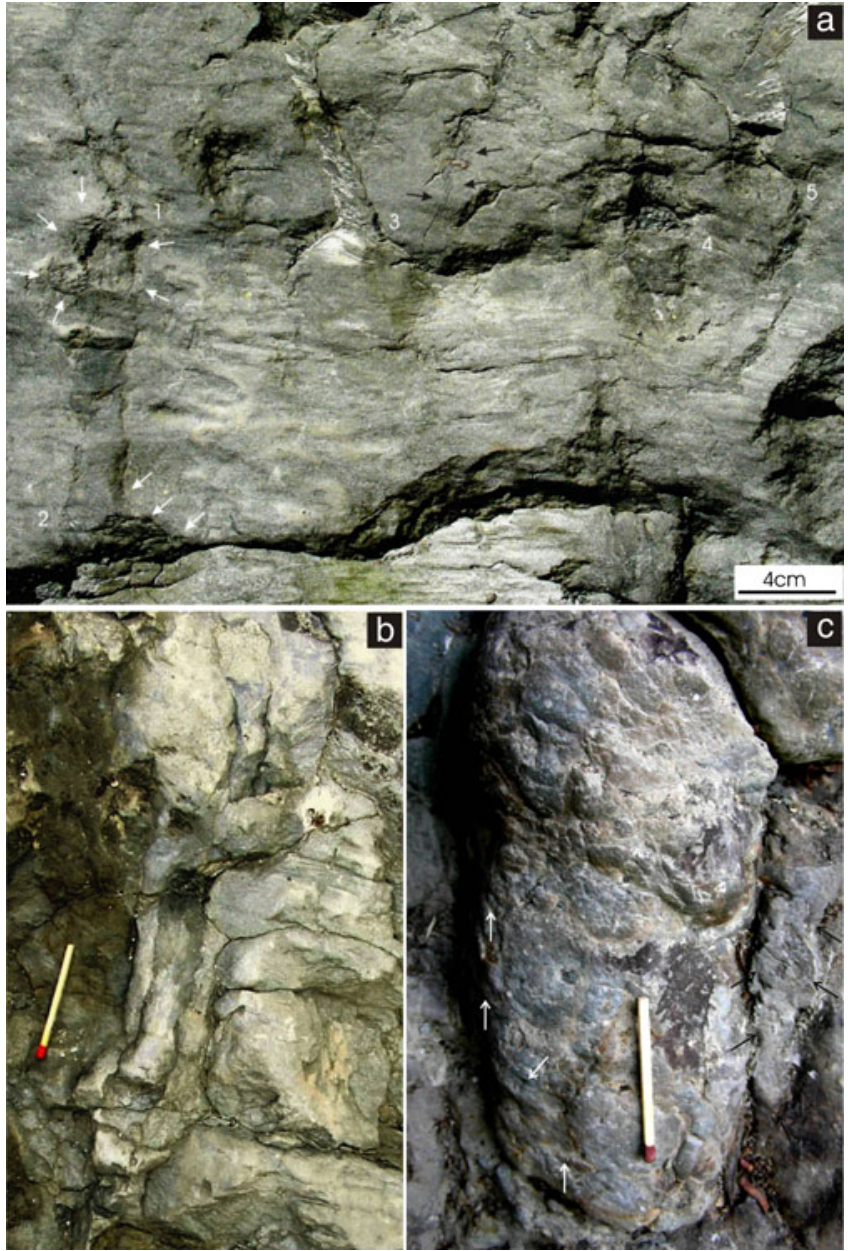

Figure 2. Biotubes (Type-1) within Facies-4 showing (a) multiple (1-2, white arrows), single (3-5) burrow enlargements and the presence of incipient rhizohalo (black arrows) in the association (Sevoke section); (b) mud liner with contrasted sediment fill in the lower (muddy) and top (sandy) part (Sevoke section, scale: Stick length $4 \mathrm{~cm}$ ); and (c) scrape marks (white arrows) on knobby, burrow-fill sediment surface and variable width of burrow lining (black arrows) in them (Leesh section, scale: Stick length $4 \mathrm{~cm}$ ).

even in a single tube (figure 2b). Subhorizontal, oblique ridges and furrows in the burrowinterior are inferred from corresponding negative features present on the surface of the burrow cast (figure 2c). Burrow openings are often wider, funnel shaped (figure 4a). Tube-fill sediments predominantly laminated with occasional concaveup laminae. Juxtaposed, branched upward tunnel openings in bed normal sections (figure 4a) are often seen as composite, coalesced burrow openings on plan (figure $4 \mathrm{~b}$ ). Tube density measured in plan view varies from $3-20$ per $\mathrm{m}^{2}$ (50 measurements). Clay pellets in tube-fill sediments may be of faecal origin as identified from ovoid to semi-spherical shapes with internal concentric shell structures detected in thin sections under microscope (figure 4c-d). Common bed junction preservation rarely allows measuring of the true tube length. Maximum observed length is $47 \mathrm{~cm}$ at Gheesh river section and $29 \mathrm{~cm}$ at Sevoke section.

Associations: These large-diameter, subvertical, enigmatic tubes in Facies-4 indicate singular dominance but for the occasional presence of sediment-filled incipient rhizoliths in the assemblage.

\subsection{Type 2 - Naktodemasis isp. (figure 5a-c)}

Description: Originally described as adhesive meniscate burrows (Bown and Kraus 1983; Hasiotis and Dubiel 1994; Hasiotis 2002; Smith et al. 2008a, b); sinuous, variably oriented, unbranched and mostly unlined burrows composed of a nested series of ellipsoidal, menisci-backfilled packets. Meniscate laminae are thin, discontinuous and texturally homogeneous. Alternating colours that correspond to matrix and mottle colours of the host rock typically accentuate the meniscate backfill (figure 5a, white arrow). Burrow walls are commonly transient with the matrix. Bounding line in some inclined burrows is bulged at intervals that correspond to menisci-backfilled packets. Burrows are 1-15 cm long and have circular to elliptical cross sections, $0.3-1.4 \mathrm{~cm}$ in diameter.

Associations: Naktodemasis isp. is abundant in Facies-2 heteroliths. These burrows are closely associated with Planolites isp. (figure 5a), probable brood chambers (figure 5b) along with Macanopsis isp., rhizoliths and rhizohaloes (figure $5 \mathrm{c}-\mathrm{d}$ ).

\subsection{Type 3 - Cylindricum isp. (figure 6a)}

Description: Vertical to nearly vertical, distinctly mud lined or unlined, straight to sinuous, unbranched burrows with unornamented surfaces. These burrows have very low widthto-length ratios that approaches 1, compared to Skolithos isp., which has one to two orders of higher width-to-length ratios. Burrows are found in low densities compared to other burrow occurrences. Burrow diameters up to $1.7 \mathrm{~cm}$. Recorded burrow length up to $6.1 \mathrm{~cm}$. Burrow terminations are rounded. Fill material is mostly structureless sandstone.

Associations: These are rare, preserved in mud dominant units of Facies-2 in which they occur in 

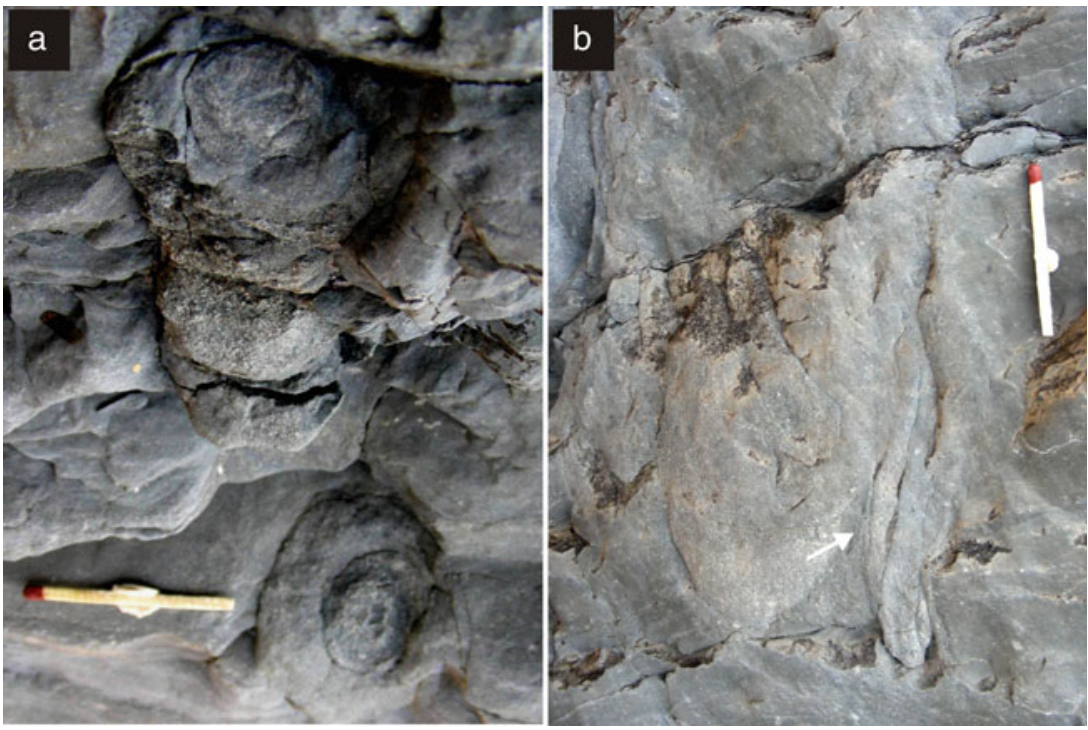

Figure 3. (a) Lag liner in Type-1 biotube around burrow-fill (visible on plan and section) and (b) distinct finer (clayey) burrow lining and coarser, sandy burrow-fill is visible in the adjacent burrows in the same outcrop (vertical section) within Facies-4 (Leesh River; scale: Stick length $4 \mathrm{~cm}$ ).

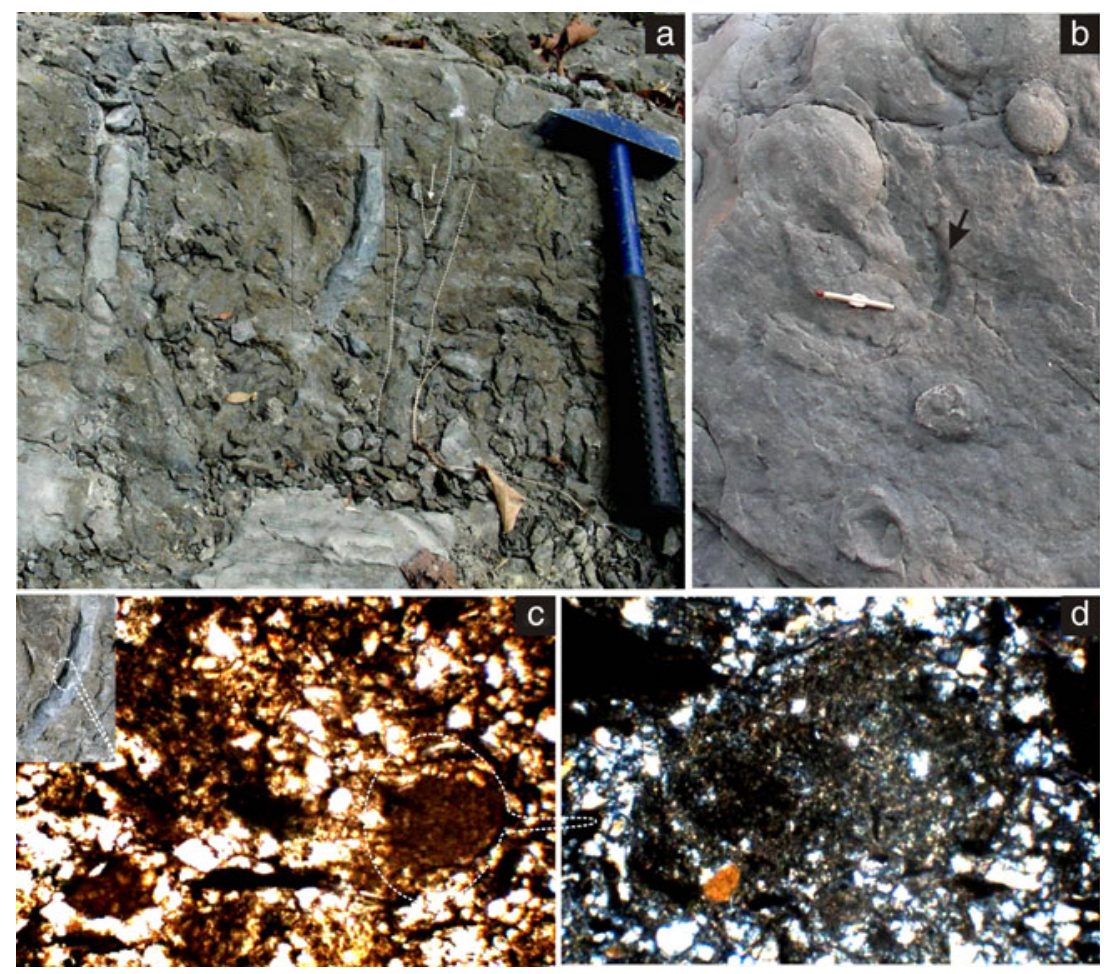

Figure 4. Type-1 enigmatic tubes within Facies-4, showing (a) branched upward tunnel opening (arrow) with funnelled top (stippled lines) (Sevoke section; scale: Hammer $30 \mathrm{~cm}$ ); (b) Knobby appearance on bed surface with coalesced, juxtaposed burrow openings (arrow) indicating upward branching of biotubes (Leesh section, scale: Stick length $4 \mathrm{~cm}$ ); (c) probable fecal pellets in some part (rectangle, marked in figure 4a) of burrow-fill sediment (photomicrograph, Slide No. SWK-091A; magnification 50×; Sevoke section); and also note (d) concentric laminae in a fecal pellet under higher magnification (photomicrograph, Slide No. SWK-09-1A; magnification 100×).

association with dominant Planolites isp. and occasional Macanopsis isp., sparse rhizoliths and rhizohaloes. At places, thin network or lenses of coaly matter occur associated with these.

\subsection{Type 4 - Planolites isp. (figures $5 a-c, 6 c$ )}

Description: Variable orientations (figure 5a, black arrows), straight to slightly sinuous, unlined, 

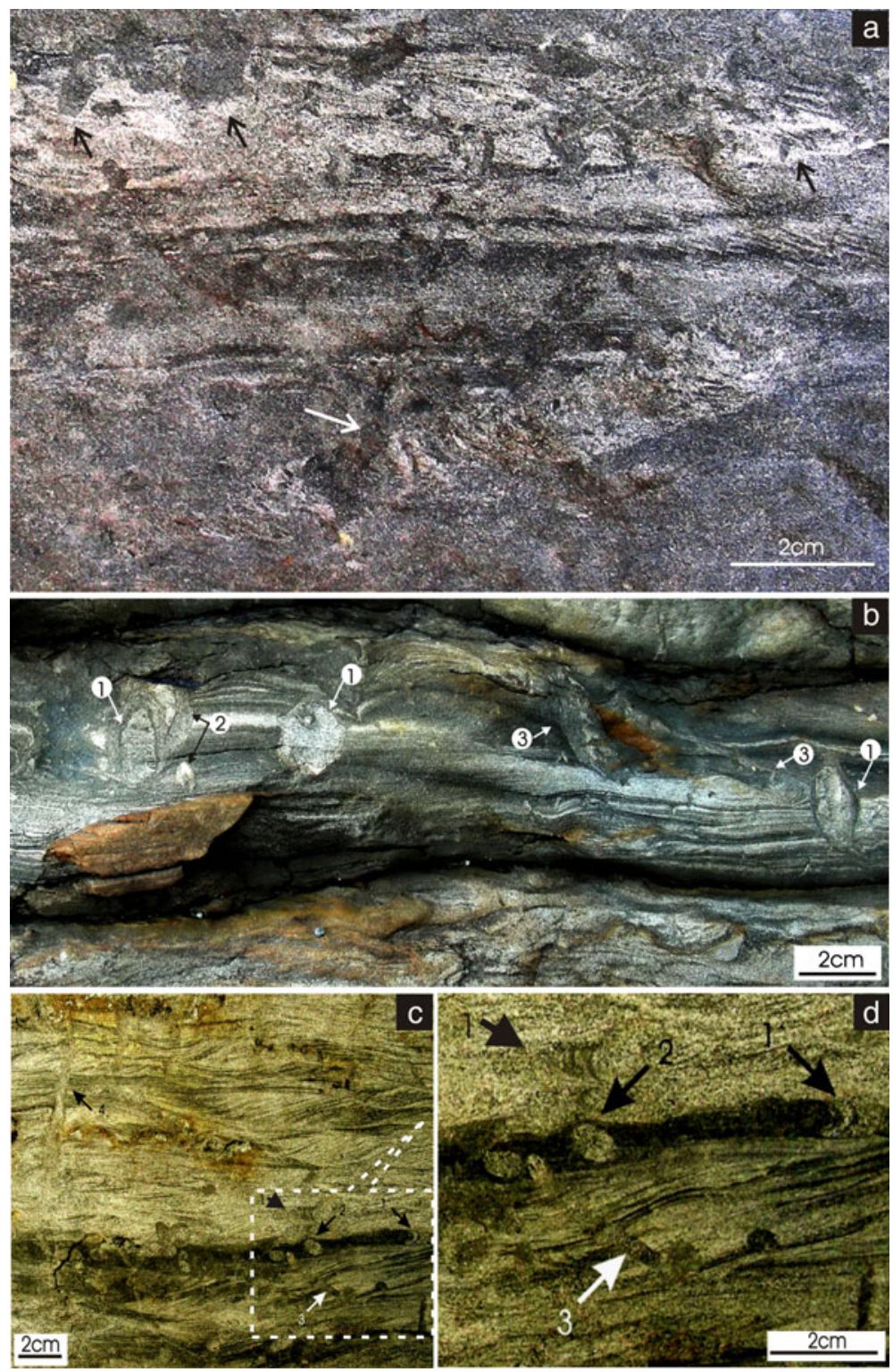

Figure 5. (a) Naktodemasis isp. (white arrow) in association with dominantly mud filled tubes of Planolites isp. (black arrows). Also note the bulging of the bounding line of the inclined burrow at intervals (Sevoke section, Facies-2); (b) Brood chambers (1) associated with Planolites isp. (2) and Naktodemasis isp. (3) and rhizohalo. Note the sharp truncation of Naktodemasis isp. against pupae-form brood chamber (right, middle) indicating continuous tiering by members of temporally differentiated trace fossil suites (Leesh section; Facies-2); (c) association of Naktodemasis isp. (1), Planolites isp. (2), Macanopsis isp. (3) and mottled, rhizohalos (4); (d) magnified view of a portion (stippled box) of figure 5(c) showing concave out backfill structures of Naktodemasis isp. (1), elliptical traces of sediment-filled sub-horizontal tubes of Planolites isp. (2) and distinct, rounded chamber at the bottom of sand-filled burrow of Macanopsis isp. (3) (Sevoke section; Facies-2).

unbranched burrows of constant width (within same burrow); circular to elliptical in cross section; structureless, homogeneous mud or sand-filled burrows (figure $5 \mathrm{a}-\mathrm{b}$ ). Burrow diameters range from 0.2 to $0.9 \mathrm{~cm}$, but most are between 0.3 and $0.5 \mathrm{~cm}$. Probable juveniles are associated with brood chambers (figure 5b, marked 2). Burrow orientation change from near vertical or inclined in siltstone intervals to predominantly horizontal, showing circular or elliptical cross section in mudstone intervals (figures 5, 6a; marked 2).
Associations: These traces are almost ubiquitous in all ichnocoenoses described under Facies-2 and less commonly in Facies-3 and Facies-4.

\subsection{Type 5 - Brood chambers (figure 5b)}

Description: Sand or mud-filled, vertically elongated, cocoon-like ellipsoids; occasional thin mud lining; long diameter varying between 2.1 and $3 \mathrm{~cm}$, with nearly constant height $v s$. width ratio 

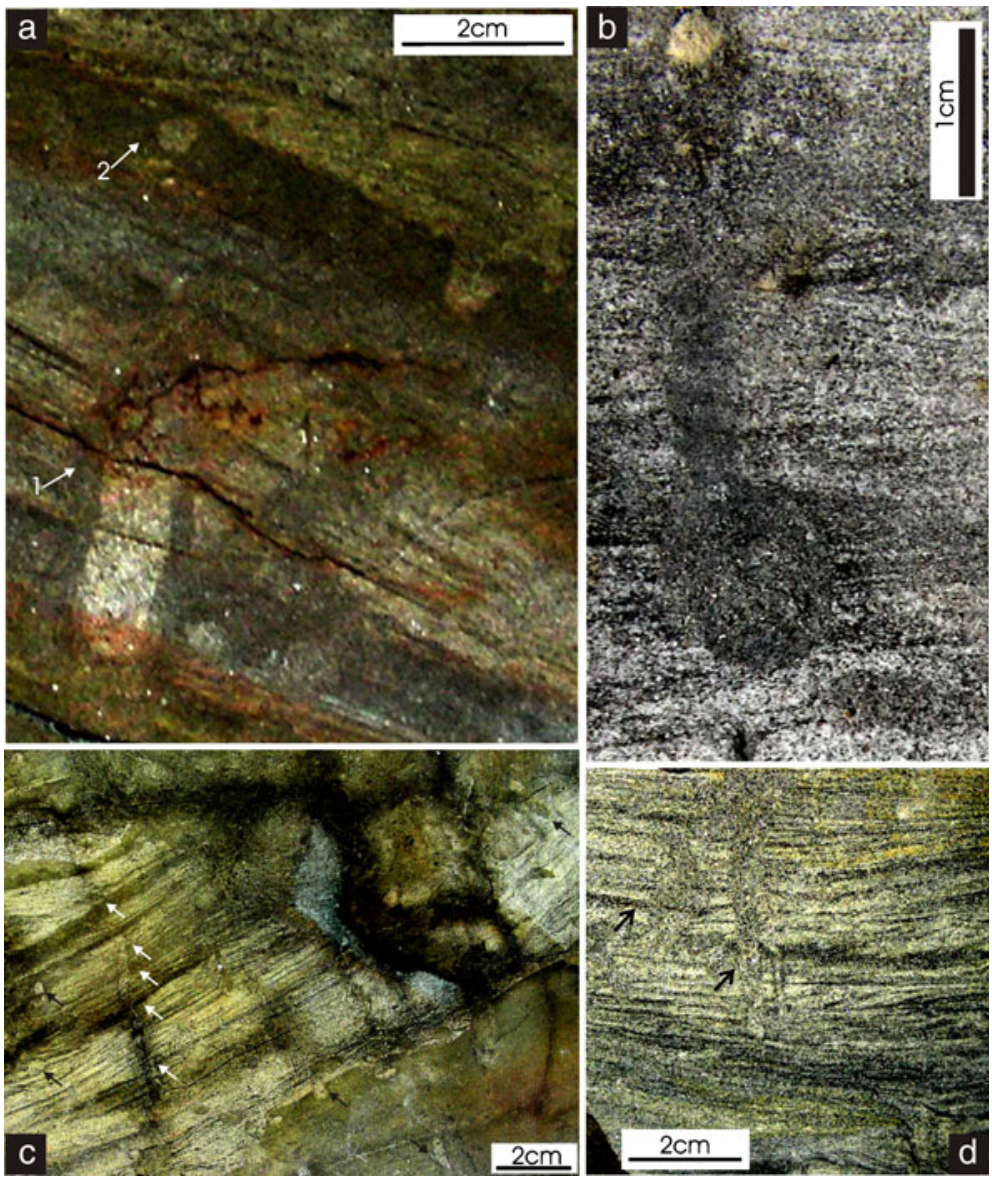

Figure 6. (a) Cylindricum isp. (1) and Planolites isp. (2). Note the distinct mud lining (arrow) and typical U-shaped, rounded bottom in Cylindricum isp. (Leesh section; Facies-2); (b) Macanopsis isp. in vertical section, showing distinct, rounded bottom and coarser sand fill near burrow opening (Sevoke section; Facies-2); (c) Planolites isp. (black arrows) and sediment-filled rhizolith (white arrows) in Gheesh River section (Facies-2); and (d) mottled rhizohaloes showing distinct branching downward (Gheesh section; Facies-2).

(between 1.7 and 1.9). These structures appear to be internally sediment filled and occasionally connected, with a number of very small Planolites isp. (figure 5b, black arrows, 2) emerging from it in different directions. Traces of Naktodemasis isp. deflect around these elliptical structures (figure 5b, marked 3).

Association: These burrows occur associated with Naktodemasis isp., Planolites isp. and incipient rhizoliths in the mud-dominant units of Facies-2.

\subsection{Type 6 - Macanopsis isp. (figures 5, 6b)}

Description: These are unlined, sand- or mudfilled burrows within Facies-2; near vertical with distinct, J-shaped subhorizontal bend terminating at a bulb; constant width (up to $0.5 \mathrm{~cm}$ ) along the tunnel length; width nearly doubled $(0.9 \mathrm{~cm})$ at bulbous end (figure 6b).
Association: These burrows occur associated with Naktodemasis isp., Cylindricum isp., Planolites isp. and incipient rhizoliths in the heterolithic packages of siltstone and mudstone of Facies-2.

\subsection{Type 7 - Sediment-filled rhizoliths (figure 6c-d)}

Description: Nearly vertical, often associated with downward-tapering and rare incipient branching (figure 6c); up to $1.3 \mathrm{~cm}$ in diameter, cylindrical structures composed of homogeneous silt or mud fill within Facies-2.

Associations: Sediment-filled rhizoliths are found in the thicker clay and thinner silt laminated intervals of Facies-2 heteroliths (figure 6c-d). Associated trace fossils include predominant Planolites isp., Cylindricum isp., Macanopsis isp. and rhizohaloes (type 8). 


\subsection{Type 8 - Rhizohaloes (figures 2a, 6d)}

Description: Vertical to subvertical; sometimes downward tapering and commonly branching (figure 6d); dark gray mottles with up to $7 \mathrm{~cm}$ in circular cross sections.

Associations: Rhizohaloes are nearly ubiquitous and occur in association with all other ichnotaxa present in Facies-2 and Facies- 4.

\section{Discussions}

This is the first report of Middle Siwalik ichnofauna from Darjeeling-Jalpaiguri sector of eastern Himalayas. Trace fossils are reported here from a sedimentary facies association, suggesting interwoven subunits of a channel-floodplain environment. Different facies-specific and facies-transgressive ichnotaxa identified from the studied Siwalik succession include Naktodemasis isp., Macanopsis isp., Cylindricum isp. and Planolites isp., along with few brood chambers and large-diameter vertical tubes of unknown origin. Often, these are associated with sediment-filled rhizoliths and/or mottled rhizohalos.

Ichnological interpretations of the varied morphotypes (1-8) observed in the studied sections may be summarized as follows:

Type-1 ichna is represented by slender, nearvertical, straight or Y-shaped, sediment-filled tunnels; distal, multiple enlargements of the tunnels; persistent mud-, sand-, or pebble-lined segments of burrows and sediment fill suggest a probable freshwater crayfish origin (Ortmann 1906; Hobbs 1974, 1988; Hasiotis and Mitchell 1993; Hasiotis and Honey 2000; Hasiotis 2002). Scrape marks interpreted from burrow margins or from more deliberate surface markings as well as the presence of faecal pellets in the burrow-fill sediments also support this prediction. Multiple tunnel enlargements throughout the length of the tubes as well as at the terminations may be interpreted as chambers. Bromley and Asgaard (1979) described similar forms with somewhat smaller dimensions as striated oblique burrow (cited in Tandon and Naug 1984). The variations of tunnel width as well as the presence of terminal tapering in some of the tunnels; incipient, apparent down-depth branching and common association with carbonate nodules, however, may also be indicative of rhizoliths. Pending detailed microscopic studies and outcrop studies in additional localities, these enigmatic tubes are held for the present as problematica showing dual characters resembling crayfish burrows and rhizoliths. We cannot rule out probable active burrow modifications on pre-existing conduits, producing these ichna.

A comprehensive statement on the implications of these enigmatic tubes is not warranted as yet, by full proof diagnoses. Indulging a crayfish origin for these tubes, multiple distal enlargements within a single burrow may be referred as reconstructed dwellings depicting sustained burrow occupancy and successive readjustments of burrowing depth. Multiple openings are also typical of crayfish burrow morphologies (Hobbs 1988; Hasiotis and Mitchell 1993; Hasiotis and Honey 2000). Permanent nature of these structures is also indicated by persistent, thick and thin burrow lining in them. Network of interpenetrating tunnels, secondary tunnel openings and the Kselected size distribution of tunnel diameters suggest a stable colony or equilibrium assemblage of the trace makers (Ekdale 1985; Vossler and Pemberton 1988; Bromley 1996). Triassic, Jurassic and Paleogene crayfish burrows show similar development of secondary tunnel openings by crosscutting, interpenetrating burrows (e.g., Hasiotis 2002). Preserved funnelled top is regarded as preservation bias that might have been formed by the collapse of sediment at the open burrow mouth. Alternatively, the wider opening with a thicker lining of sediment may record the initial burrow construction by removal of more material to accommodate excavated sediment produced by the deepening of the burrow (Hasiotis and Mitchell 1993; Hasiotis and Honey 2000). Tube-fill sediments of contrasted composition within a single burrow suggest passive filling and bed junction preservation. Occasional presence of incipient laminae and observed concavity in them is intriguing in this context. Both sand and mud-filled tubes in the same population may be interpreted as the mixing of temporally differentiated populations through tiering.

Type-2 ichna, identified as Naktodemasis isp., is interpreted as the intermittent locomotion and dwelling traces of burrowing beetles of hemipteran or coleopteran affinity (Hasiotis 2002, 2008; Smith et al. 2008b; Smith and Hasiotis 2008; Counts and Hasiotis 2009). A terraphilic to hygrophilic moisture preference and a compatible rooted $\mathrm{A}$ and upper B horizons of the soil profile is indicated by the association of Naktodemasis isp. with sediment-filled rhizoliths (Hasiotis 2008; Smith et al. 2008b; Counts and Hasiotis 2009). A relatively higher diversity association of this ichna with brood chambers, rhizoliths and Planolites isp. at distinct stratigraphic intervals indicates an equilibrium assemblage in this context, compatible with a short-term stable groundwater profile. Longer term stability in the groundwater conditions, 
coupled with lower sedimentation rates, would have produced greater bioturbation intensity in which Naktodemasis would have destroyed all original primary bedding.

Type-3 ichna are almost similar to Cylindricum, in that they are short, smooth-walled and predominantly vertical shafts with gently rounded terminations (cf. Smith et al. 2008b). The lack of other diagnostic morphologies limits the assignment of these burrows to any specific group of tracemakers. Cylindricum can be made by a variety of different arthropods, including spiders and insects living in subaerial conditions where the water table is close to the surface (Stanley and Fagerstrom 1974; Ratcliffe and Fagerstrom 1980; Hasiotis 2002).

Predominance of horizontal burrows of Planolites isp. (Type-4) in mudstones and inclined to near vertical burrow segment in siltstones within Facies-2 heteroliths may indicate a preference for mud. The distinct wall and structureless fill, particularly in the vertical segment of these burrows, however, suggests passive, sediment-filled, open burrows. The presence of Planolites isp. in different ichnocoenoses indicates the simple character of this burrow morphology, which can be created by nearly invertebrate living above or below the water table. Low abundance of Planolites isp., where they occur in association with other ichna ( Naktodemasis isp., Macanopsis isp. and Cylindricum isp.) indicate a K-selected equilibrium assemblage compatible with stable, less stressed depositional milieu. In contrast, their monospecific occurrences in distinct stratigraphic interval in good numbers indicate their colonization as an opportunist colonizer (Ekdale 1985; Bromley 1996). Millimetrethick heterolithic layers within Facies-2 that are thoroughly riddled by relatively shallow burrows of Planolites isp. in this context, probably indicate a floodplain depositional milieu where temporary environmental shifts have allowed colonization (Pollard 1988). Here, typically mud-filled burrows within thin sandy-silty layers represent the passage of the burrower through a sandy unit from an overlying mud (e.g., Taylor et al. 2003).

Sharp deflection of Naktodemasis isp. around the Type-5 ichna perhaps indicate a continued tiering of the former, within a stable ichnocoenose in which, Type- 5 sediment-filled structures represent a relatively earlier colonization. These are interpreted as brood chambers from the connected tiny strands of Planolites isp. that are in this context, interpreted to represent exit burrows of juveniles. Presence of these probable brood chambers indicates periods of well-drained subsurface condition with optimal moisture content in the sediment, allowing safe exit of juveniles.

Though the type materials of Macanopsis (Type-6) were described as marine, these were later recorded in the pointbar deposits of the fluvial deposits (Bown 1982; Bown and Kraus 1983), fluvial floodplain (Hasiotis et al. 1993) and in braided fluvial environment (Fernandes and Carvalho 2006). These structures were attributed to a variety of invertebrate trace makers including insects, spiders, decapods and molluscs (cf. Bown and Kraus 1983). Facies association of this ichnotaxon within pointbar deposits in this context is compatible with its freshwater allegiance. Bulbous end in these burrows suggest a dwelling structure (domichnia). Structureless sand and mud fill indicate open burrows that were passively filled. Association with Naktodemasis isp. and incipient rhizohaloes suggests intermittent well-drained conditions that prevailed in the accumulated sediments.

Type-7 morphotypes are interpreted as root pathways, in-filled with sediments after the decay of the original roots. Overall association indicates a fluctuating hydrologic condition but root placement in the vadose zone of the groundwater profile (Glinski and Lipiec 1990). This behaviour would be referred to as terraphylic to hygrophilic in that the plant roots are seeking out areas of pore spaces filled with air and water (Hasiotis 2002, 2007).

The branching patterns and circular cross sections of Type- 8 mottled structures suggest that these are formed in the depletion zones resulting from surface-water gleying within and adjacent to original roots (Schwertmann 1993; Kraus and Hasiotis 2006). Seasonal, saturated soil conditions followed by periods of better drainage and lower water tables may be suggested from this association of mottles (Bigham et al. 1978; Torrent et al. 1980).

Overall low-diversity ichno-assemblages in the studied sections is compatible with other recorded low-diversity fluvial ichnocoenoses, which is indicative of high sedimentation rates and sediment accumulation rates (e.g., Hasiotis 2004, 2007).

A low density, but relatively more diverse Naktodemasis-Macanopsis-Cylindricum-Planolites ichno-assemblage (occasionally with probable brood chambers) within thinly laminated heterolithic Facies-2 probably indicate an equilibrium assemblage compatible with periods of stability in the depositional environment in terms of rate of sedimentation and shifts in hydrologic surface. All these ichnotaxa (except Planolites isp.) are facies specific in their occurrences. A distinctly different ichnocoenosis within sandstone-dominant intervals of Facies-2 is represented by monospecific occurrence of high density population of Planolites that, in this context, indicate a stressed, opportunistic colony (Ekdale 1985; Bromley 1996). Still another monospecific colonization of enigmatic large diameter, vertical tubes within Facies-4 (with occasional, rare Planolites isp.) records 
probable reburrowing events. Association of rhizoliths and rhizohalos of varying descriptions also suggests varying moisture content in the sediment matrix. Historically, Siwalik depositional milieu is reported to record phased episodic uplifts of the Himalaya and the remarkable fall of sea level in the Indian shelf, that significantly affected the sedimentation, paleoclimatic and paleohydrological conditions in the Cenozoic around the area (Johnson et al. 1983; Valdiya 1998; Vaidyanadhan and Ramakrishnan 2008). Subtle changes in the hydrologic surface vis-a-vis shifts in media (=substrate) elevation and sedimentation rate appear to put major constraints in this depositional regime. Repetitive adjustment of burrowing depths in enigmatic burrows, mud and lag liners in them; recurrence of equilibrium and opportunist colonization events; varied mode of preservation of plant roots may thus probably be interpreted as feed-back responses of middle Siwalik ichnofauna to repetitive changes in depths of water table in a floodplain environment.

\section{Conclusions}

Monospecific colonies of Planolites isp. defining a pioneer, opportunistic (r-selected) assemblage and Naktodemasis-Planolites-CylindricumMacanopsis equilibrium (K-selected) assemblage along with enigmatic, monospecific large diameter vertical burrows from the Neogene Middle Siwalik sedimentary succession of the Darjeeling Himalayas developed in a continental fluviatile environment. Recurrence of monospecific colonies of Planolites isp. indicate stressed conditions interpreted in terms of subtle changes in the depth of paleohydrologic surface. Relative quieter periods in the depositional set-up are represented by equilibrium assemblage. Ethological interpretation of large diameter enigmatic biotubes may offer valuable information in this context, pending their formal diagnosis. Taphonomic aspects of preserved rhizoliths or rhizohaloes further indicate varied moisture level in the substrate. Addition of new faunal data from eastern Himalayas help to put constraints on middle Siwalik sedimentation milieu in the studied part of the basin and delineates an ichnological-paleoecological frame for further study on continental Siwalik sedimentation.

\section{Acknowledgements}

Authors are thankful to anonymous reviewers for their meticulous review and improvement suggestions. Heart-felt thanks to Prof. Nibir Mandal, Associate Editor, JESS for his helpful suggestions during the preparation of this manuscript.

\section{References}

Acharyya S K, Dutta A K and Sastry M V A 1976 Siwalik stratigraphy and its bearing on the main boundary fault; Geol. Surv. India Misc. Publ. 41 67-79.

Agarwal S C and Singh I B 1983 Palaeoenvironment and trace fossils of the Middle Siwalik sediments, Haridwar, Uttar Pradesh; J. Palaeontol. Soc. India 28 50-55.

Banerjee I and Banerjee S 1982 A coalescing alluvial fan model of Siwalik sedimentation: A case study in eastern Himalaya; Geol. Surv. India Misc. Publ. 41 1-12.

Bigham J M, Golden D C, Buol S W, Weed S B and Bowen L H 1978 Iron oxide mineralogy of well-drained ultisols and oxisols: Pt. 2. Influence on color, surface area and phosphate retention; Soil Sci. Soc. Am. J. 42 825-830.

Bown T M 1982 Ichnofossils and rhizoliths of the nearshore fluvial Jebel Qatrani Formation (Oligocene), Fayum Province, Egypt; Palaeogeogr. Palaeoclimatol. Palaeoecol. 40 255-309.

Bown T M and Kraus M J 1983 Ichnofossils of the alluvial Willwood Formation (Lower Eocene), Bighorn Basin, Northwestern Wyoming, USA; Palaeogeogr. Palaeoclimatol. Palaeoecol. 43 95-128.

Bromley R G 1990 Trace fossils: Biology and taphonomy; Special Topics in Palaeontology (London: Unwin Hyman) 3280 p.

Bromley R and Asgaard U 1979 Triassic freshwater ichnocoenoses from Carisberg Fjord, East Greenland; Palaeogeogr. Palaeoclimatol. Palaeoecol. 28 39-80.

Bromley R G 1996 Trace fossils: Biology taphonomy and application; 2nd edn, Chapman and Hall, 361p.

Chaudhri R S 1972 Heavy minerals from the Siwalik formations of northwestern Himalayas; Sedim. Geol. 8 77-82. http://resolver.scholarsportal.info/resolve/doi/10.1016/ 0037-0738(72)90042-5.

Counts J W and Hasiotis S T 2009 Neoichnological experiments documenting burrowing behaviors and traces of the masked chafer beetle (Coleoptera: Scarabaeidae: Cyclocephala sp.): Behavioral significance of extant soildwelling insects to understanding backfilled trace fossils in the continental realm; Palaios 24 74-91.

Dubiel R F and Hasiotis S T 2011 Deposystems, paleosols and climatic variability in a continental system: The Upper Triassic Chinle Formation, Colorado Plateau, USA; In: From river to rock record: The preservation of fluvial sediments and their subsequent interpretation (eds) Davidson S and North C; SEPM Spec. Publ. 97 393-421.

Dubiel R F, Skipp G and Hasiotis S T 1992 Continental depositional environments and tropical paleosols in the Upper Triassic Chinle Formation, Eagle Basin, Western Colorado; In: Mesozoic of the western interior (ed.) Flores R M, Field Guide Book, USA, pp. 21-37.

Ekdale A A 1985 Paleoecology of the marine endobenthos; Palaeogeogr. Palaeoclimatol. Palaeoecol. 50 63-81.

Fernandes A C S and Carvalho I D 2006 Invertebrate ichnofossils from the adamantina formation (Bauru basin, late cretaceous), Brazil; Rev. Bras. Paleontol. 9 211-220.

Gansser A 1964 Geology of the Himalaya (New York, USA: Interscience Publishers), 289p.

Glinski J and Lipiec J 1990 Soil physical conditions and plant roots (Boca Raton, Florida: CRC Press), 250p.

Häntzschel W 1975 Trace fossils and problematica; In: Treatise on invertebrate paleontology Pt. W Miscellanea (ed.) Teichert C, Geological Society of America and University of Kansas Press, Boulder, Colorado, Lawrence, Kansas, pp. W1-W269.

Hasiotis S T 1990 Identification of the architectural and surficial burrow morphologies of ancient lungfish and crayfish burrows: Their importance to ichnology; In: Proceedings, Pacific Rim 90 Congress, Australia, pp. 529-536. 
Hasiotis S T 2002 Continental Trace Fossils; Society for Sedimentary Geology, Tulsa, Oklahoma, 134p.

Hasiotis S T 2004 Reconnaissance of upper jurassic morrison formation ichnofossils, Rocky Mountain Region, USA: Paleoenvironmental, stratigraphic and paleoclimatic significance of terrestrial and freshwater ichnocoenoses; Sedim. Geol. 167 177-268.

Hasiotis S T 2007 Continental ichnology: Fundamental processes and controls on trace fossil distribution; In: Trace fossils: Concepts, problems, prospects (ed.) Miller W (Amsterdam: Elsevier), pp. 262-278.

Hasiotis S T 2008 Reply to the comments by Bromley et al. of the paper "Reconnaissance of the upper Jurassic Morrison formation ichnofossils, rocky mountain region, USA: Paleoenvironmental, stratigraphic and paleoclimatic significance of terrestrial and freshwater ichnocoenoses"; Sedim. Geol. 208 61-68.

Hasiotis S T and Dubiel R F 1994 Ichnofossil tiering in Triassic alluvial paleosols: Implications for Pangean continental rocks and paleoclimate; In: Pangea: Global environments and resources (eds) Beauchamp B, Embry A F and Glass D; Canadian Society of Petroleum Geologists $17311-317$.

Hasiotis S T and Honey J 2000 Paleocene continental deposits and crayfish burrows of the laramide basins in the Rocky Mountains: Paleohydrologic and stratigraphic significance; J. Sediment. Res. 70 127-139.

Hasiotis S T and Mitchell C E 1993 A comparison of crayfish burrow morphologies: Triassic and Holocene fossil, paleoand neo-ichnological evidence and the identification of their burrowing signatures; Ichnos 2 291-314.

Hasiotis S T, Aslan A and Bown T M 1993 Origin, architecture and paleoecology of the Early Eocene continental ichnofossil Scaphichnium hamatum, integration of ichnology and paleopedology; Ichnos 3 1-9.

Hobbs H H 1974 Synopsis of the families and genera of crayfishes (Crustacea: Decapoda); Smithsonian Contrib. Zool. 164 1-32.

Hobbs H H 1988 Crayfish distribution, adaptive radiation and evolution; In: Freshwater crayfish: Biology, management and exploitation (eds) Holdich D M and Lowery R S, Croom Helm, London, pp. 52-82.

Jain V and Sinha R 2003 River systems in the gangetic plains and their comparison with the Siwaliks: A review; Curr. Sci. 84 1025-1033. http://home.iitk.ac. in/ rsinha/Publications.htm.

Johnson G D, Opdyke N D, Tandon S K and Nanda A C 1983 The magnetic polarity stratigraphy of the Siwalik group at Haritalyangar (India) and a new last appearance datum for Ramapithecus and Sivapithecus in Asia; Palaeogeogr. Palaeoclimatol. Palaeoecol. 44 223-249.

Keighley D G and Pickerill R K 2003 Ichnocoenoses from the carboniferous of eastern Canada and their implications for the recognition of ichnofacies in nonmarine strata; Atlantic Geology 39 1-22. http://www.colorado.edu/ GeolSci/faculty/pdf/Kraus_Hasiotis_2006.pdf.

Kraus M J and Hasiotis S T 2006 Significance of different modes of rhizolith preservation to interpreting paleoenvironmental and paleohydrologic settings: Examples from Paleogene paleosols, Bighorn Basin, Wyoming, USA; J. Sedim. Res. 76 633-646.

Kumar R, Sangode S J and Ghosh S K 2004 A multistorey sandstone complex in the Himalayan Foreland Basin, NW Himalaya, India; J. Asian Earth Sci. 23 407-426.
Kundu A, Matin A and Mukul M 2012 Depositional environment and provenance of Middle Siwalik sediments in Tista valley, Darjiling District, Eastern Himalaya, India; J. Earth Syst. Sci. 121(1) 73-89.

Mallet F R 1875 On the geology and mineral resources of the Darjiling District and the Western Duars; Geol. Surv. India Memoir 11 1-50.

Ortmann A E 1906 The crawfishes of the state of Pennsylvania; Mem. Carnegie Mus. 2 343-521.

Pollard J E 1988 Trace fossils in coal-bearing sequences; J. Geol. Soc. 145 339-350.

Raju A T R 1969 Observation on the petrography of clastic sediments of Himalayan foothills of North India; ONGC Bull. 4 5-15.

Ratcliffe B C and Fagerstrom J A 1980 Invertebrate lebensspuren of holocene floodplains: Their morphology, origin and paleoecological significance; J. Paleontol. 54 614-630. http://digitalcommons.unl. edu/entomologypapers/136.

Sanyal P, Bhattacharya S K, Kumar R, Ghosh S K and Sangode S J 2005 Palaeovegetational reconstruction in late miocene: A case study based on early diagenetic carbonate cement from the Indian Siwalik; Palaeogeogr. Palaeoclimatol. Palaeoecol. 228 245-259.

Schwertmann U 1993 Relations between iron oxides, soil color and soil formation; J. Soil Sci. 31 51-69.

Seilacher A 1964 Biogenic sedimentary structures; In: Approaches to Paleoecology (eds) Imbrie J and Newell N (New York: Wiley), pp. 296-316.

Smith J J and Hasiotis S T 2008 Traces and burrowing behaviors of the cicada nymph Cicadetta calliope: Neoichnology and paleoecological significance of extant soil-dwelling insects; Palaios 23 503-513.

Smith J J, Hasiotis S T, Kraus M J and Woody D T 2008a Naktodemasis bowni: New ichnogenus and ichnospecies for adhesive meniscate burrows (amb) and paleoenvironmental implications, paleogene Willwood formation, Bighorn basin, Wyoming; J. Paleontol. 82 267-278.

Smith J J, Hasiotis S T, Kraus M J and Woody D T 2008b Relationship of floodplain ichnocoenoses to paleopedology, paleohydrology and paleoclimate in the Willwood Formation, Wyoming, during the paleocene-eocene thermal maximum; Palaios 23 683-699.

Stanley K O and Fagerstrom J A 1974 Miocene invertebrate trace fossils from a braided river environment, western Nebraska, USA; Palaeogeogr. Palaeoclimatol. Palaeoecol. $1563-82$.

Tandon S K and Naug B 1984 Facies-trace fossil relationships in a plio-pleistocene fluvial sequence, the upper Siwalik subgroup, Punjab sub-Himalaya, India; Palaeogeogr. Palaeoclimatol. Palaeoecol. 47 277-299.

Taylor A, Goldring R and Gowland S 2003 Analysis and application of ichnofabric; Earth Sci. Rev. 60 227-259.

Torrent J, Schwertmann U and Schulze D G 1980 Iron oxide mineralogy of some soils of two river terrace sequences in Spain; Geoderma 23 191-208.

Vaidyanadhan R and Ramakrishnan M 2008 Geology of India; 2nd edn, Geological Society of India, Bangalore, 994p.

Valdiya K S 1998 Dynamic Himalaya; University Press, India, 178p.

Vossler S M and Pemberton S G 1988 Skolithos in the upper cretaceous cardium formation: An ichnofossil example of opportunistic ecology; Lethaia 21(4) 351-362. 